\title{
PROBLEMS OF THE AGED WITH SPINAL CORD INJURIES
}

\author{
By Alain Rossier, M.D.* \\ and ERnest Bors, M.D., D.A.B., F.A.C.S. \\ Spinal Cord Injury Service of the Veterans Administration Hospital, \\ Long Beach, California, and the Department of Surgery, University of California \\ School of Medicine, Los Angeles, California 90024
}

\section{INTRODUCTION}

MANY papers have been written on the subject of spinal cord injury. None of them has specifically dealt with problems encountered in older patients. This report will deal exclusively with patients who have been processed in this Spinal Cord Injury Center from its opening on I April I946 to 7 July I964. These patients are either living or have died in the seventh decade of life.

\section{OBSERVATIONS}

Two groups will be presented: (a) patients with non-traumatic lesions who will be considered only in regard to their mortality as compared with the mortality of the patients' group with traumatic lesions, and $(b)$ patients with traumatic lesions of the spinal cord caused mainly by car accidents and falls; the problems of those who have survived up to this writing will be discussed in detail.

There were 32 patients (3I males and I female) with non-traumatic lesions and 73 patients ( 72 males and I female) with traumatic lesions.

\section{NON-TRAUMATIC LESIONS}

The following aetiologies were noted: arachnoiditis in nine patients (including chemical damage by spinal anaesthesia due to protargol or methylene blue injection), neoplasm in five, discogenic disease in four, spinal vascular accident or malformation in six, infectious transverse myelitis in three, vertebral osteomyelitis in three, unknown in two patients.

The age of the patients ranged from 22 to 72 years at the onset of the nontraumatic condition and the survival time ranged from one year to 50 years. There were I5 deaths and I 7 survivors, i.e. a mortality of 47 per cent.

The level and extent of lesions were as follows: complete cervical, 2; incomplete cervical, I; complete thoracic, IO; incomplete thoracic, IO; complete lumbar, 2 ; incomplete lumbar, 7 .

The mortality was 66 per cent. in the group with cervical lesions, 50 per cent. in the group with thoracic lesions, but only 33 per cent. in the group with lumbar lesions.

* Aided by a Scholarship of the Swiss Academy of Medical Sciences, Foundation of Medicine and Biology, and by a grant of the American-Swiss Foundation for Scientific Exchange. 


\section{TRAUMATIC LESIONS}

Mortality. The age at the time of injury ranged from I9 to 76 years and the survival time ranged from one year to 47 years. There were 21 deaths and 52 survivors, i.e. a mortality of 29 per cent.

The distribution of the segmental level and extent of lesions of all 73 patients was as follows: complete cervical, I; incomplete cervical, 24; complete thoracic, 26; incomplete thoracic, I2; complete lumbar, 4 ; incomplete lumbar, 6.

The mortality was 32 per cent. in the group with cervical lesions, 28 per cent. in thoracic lesions and only 20 per cent. in lumbar lesions.

The age of the deceased ranged from 60 to 77 years. The survival time until death ranged from $I$ to 47 years.

The one patient with a complete cervical lesion at $\mathrm{C}_{7}$ died within one year after injury; he was 68 at death.

The seven patients with incomplete cervical lesion (C5-C8), died within $\mathrm{I}_{5}$, $4,3,3, \mathrm{I}, \mathrm{I}$, I years after injury, respectively; their respective ages at time of death were $62,60,66,66,63,62,77$.

The seven patients with complete thoracic lesions died 47, 25, 20, I5, I0, IO, 2 years after injury, respectively; their respective ages at time of death were 67,65 , $68,68,60,74,66$.

The four patients with incomplete thoracic lesions died within 45, 8, 7, 2 years after injury, respectively; their respective ages at time of death were $65,62,60,62$.

The two patients with complete lumbar lesions died within 30 and Io years after injury, respectively; their respective ages at time of death were 75 and 60.

The cause of death was known in 18 instances.

Related to the injury were the following causes of death in seven patients: septicaemia (renal origin); atelectasis plus pulmonary congestion (cervical lesion); uremia; nephrolithiasis plus pyelonephritis; amyloidosis; meningitis plus bronchopneumonia; respiratory failure (cervical lesion). Considered unrelated were the following causes in eleven patients: carcinoma of stomach; bronchogenic carcinoma; lobar pneumonia; four myocardial infarctions; acute liver atrophy (based upon Laënnec's cirrhosis); three cerebrovascular accidents.

Survival Time. There are 52 patients still alive to be reported here in detail. Their ages range from 60 to 76 . Their survival time ranges from one year to 40 years. The following distribution regarding level and extent of lesion was found: complete cervical, zero; incomplete cervical, I7; complete thoracic, 20; incomplete thoracic, 8; complete lumbar, 2; incomplete lumbar, 6.

The survival time of the patients with incomplete cervical lesions ranges from I to 20 years; 6 patients were injured before and II after the age of 60 . Patients with complete thoracic lesions have survived from 3 to 40 years; I 5 patients were injured before and 5 after the age of 60 . Those with incomplete thoracic lesions survived from 5 to 20 years; six patients were injured before and one after the age of 6o. The survival time of patients with complete lumbar lesions ranges from Io to I 5 years; two patients were injured before the age of 6o. Patients with incomplete lumbar lesions survived from I5 to 25 years; six patients were injured before the age of 60 .

\section{UROLOGICAL ASPECTS}

Bladder Status. This was judged on the basis of the condition upon discharge from hospital. At the time of the survey the following 27 ( 52 per cent.) 
patients were catheter free: incomplete cervical, Io; complete thoracic, 9; incomplete thoracic, 5; complete lumbar, zero; incomplete lumbar, 3. Among these patients were two, one with an incomplete cervical, the other with an incomplete thoracic lesion, who never required catheter drainage at any time after injury.

Following the injury, 47 patients had been treated with indwelling Foley catheters and three patients with suprapubic cystostomies. Table I.

The catheter-free state was originally reached by 30 patients as indicated in

TABLE I

\begin{tabular}{|c|c|c|c|c|c|}
\hline & $\begin{array}{l}\text { Within } \\
3 \text { weeks } \\
\text { to } 4 \text { mths. }\end{array}$ & $\begin{array}{l}\text { Within } \\
6 \text { mths. }\end{array}$ & $\begin{array}{c}\text { Within } \\
\text { I yr. }\end{array}$ & $\begin{array}{l}\text { Within } \\
2-5 \mathrm{yr} \text {. }\end{array}$ & $\begin{array}{l}\text { Within } \\
5 \text { yr. + }\end{array}$ \\
\hline Cervical, incomplete & 4 & - & 3 & - & - \\
\hline Thoracic, complete & - & - & 5 & 6 & I \\
\hline Thoracic, incomplete & - & I & 2 & - & I \\
\hline Lumbar, complete & - & - & 2 & - & - \\
\hline \multirow[t]{2}{*}{ Lumbar, incomplete } & - & I & 3 & - & I \\
\hline & 4 & 2 & I5 & 6 & 3 \\
\hline
\end{tabular}

On examining the ages at which the catheter-free state was reached it was found that nine patients were more than 60 and one patient more than 70 years old. Of these Io patients, seven had incomplete cervical or thoracic lesions, and three had complete thoracic lesions.

Bladder Stones. These were present in I I of the living patients.

Ureteral and Renal Stones. The distribution according to level and extent of lesions of the living patients is shown in Table II.

TABLE II

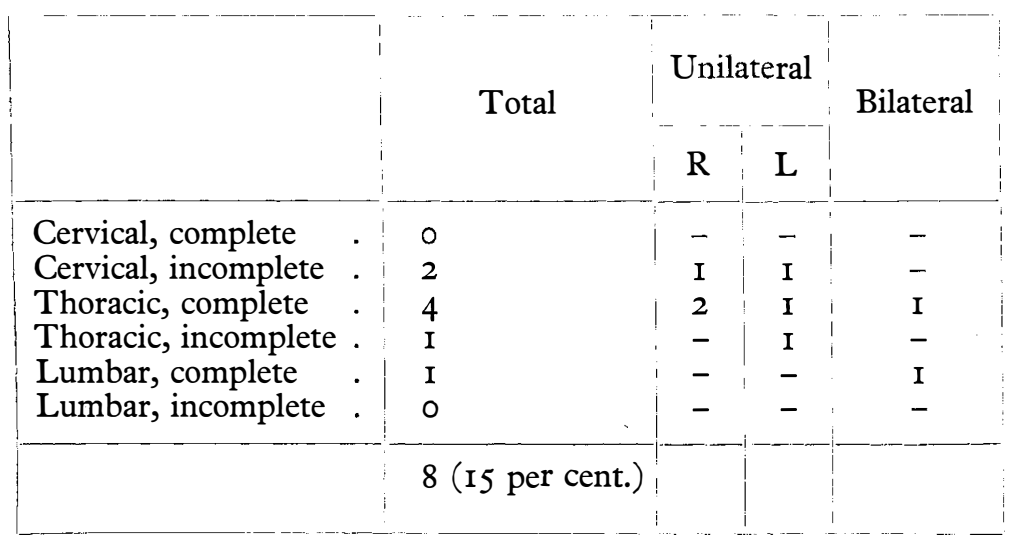


Time Lapse and Stone Formation. Stones were produced within the first year by two patients, within the fourth by one patient, within the fifth and seventh by two patients, respectively, within the eighth and fifteenth repeatedly by the same patient, within the tenth year by one patient and within the fourteenth and fifteenth repeatedly by the same patient.

Pseudopapillomata of Bladder and Urethra. These were present in five patients (IO per cent.) and responded to conservative treatment with silver nitrate (I:IO,OOO) lavages. Histological verification by transurethral biopsy was obtained. Of these five patients, two were catheter-free.

Urethral Pathology. Penoscrotal pathological changes (fistula and/or diverticulum) were observed in three patients, one year (in two patients) and four years (in one patient) following injury. In one patient rupture of the urethra at the time of injury caused the penoscrotal fistula. Another patient developed this condition while on external (condom) drainage; the third patient had just changed from catheter to condom drainage when the fistula was noticed.

Vesico-ureteral Reflux. This condition was present in seven patients (I3 per cent.); six had an upper motor neurone type of bladder function and one had a lower motor neurone type. These refluxes were all recorded as unilateral.

Transurethral Resection of the Vesical Neck (TUR): This was done in I 5 ( 28 per cent.) patients of whom nine patients had an upper and six patients a lower motor neurone type of bladder function. Of the nine patients with upper motor neurone lesions, 7 became catheter-free following TUR; four had a complete, five an incomplete lesion. Of the six patients with lower motor neurone lesions, only two became catheter-free following TUR. A TUR had to be repeated in five patients, of whom three had upper and two had lower motor neurone types of bladder. At this Spinal Cord Injury Center a TUR is not performed before the first year after injury has been reached. It is known that a late TUR (6 and I2 years following injury) may lead to a catheter-free state.

Epididymitis. This complication occurred in $\mathrm{I} 6$ patients (3I per cent.). Epididymitis with urethral catheter occurred in II patients and without catheter in five. This complication was unilateral in 13 patients and bilateral in three. Vasoresection was done bilaterally in three patients and unilaterally in one. Epididymectomy was done bilaterally in one patient. Hemi-castration was done in three patients among whom was one with previous bilateral epididymectomy.

\section{BOWEL FUNCTION}

Upon arrival at this Spinal Cord Injury Center I I patients used enemas from which eight could be weaned after re-training. The majority of patients (36) used digital stimulation and/or rectal suppositories, and the remaining used strain. Those with bowel movement, induced exclusively by abdominal strain, had incomplete lesions.

\section{DECUBITUS ULCER}

Pressure ulcers occurred in 30 patients ( 58 per cent.) of whom I9 (63 per cent.) had a complete lesion. Their distribution in regard to area of occurrence in the 
order of frequency was as follows: sacrum, ischium, trochanter, heel, knee, fibula. Surgical repair was performed in the following instances: sacral ulcers, 6; ischial ulcers, 6; trochanteric ulcers, 2; i.e. I4 operations were necessary in 62 pressure ulcers. This shows that 77 per cent. of ulcer healed under conservative treatment.

Not included in this number of decubitus ulcers is the number of burns which occurred in three patients.

\section{ORTHOPAEDIC ASPECTS}

Fractures. There were seven patients who sustained fractures at the time of injury which concerned upper and lower extremities and the thoracic cage.

There were four patients ( 8 per cent.) who incurred fractures of the lower extremities following injury; three of these patients had upper and one had lower motor neurone lesions.

\section{NEUROLOGICAL AND NEUROSURGICAL ASPECTS}

Laminectomy. Twenty-three patients (44 per cent.) underwent this procedure, performed elsewhere in the majority of patients; of these, I I patients had complete and 12 had incomplete lesions. Eight patients had cervical, I 2 thoracic and 3 lumbar lesions. The time of laminectomy ranged from 24 hours to 9 months after injury. There was no objective neurological improvement following surgery.

Spasticity. Incapacitating spasticity necessitating destructive procedures was present in only three patients, i.e. 7 per cent. of all patients with upper motor neurone lesions. Conservative remedial procedures, such as muscle-relaxant drugs, muscle fatiguing through physical and hydrotherapy, peripheral nerve anaesthesias, etc., were successful in six patients.

Pains. Incapacitating pain required spinothalamic tractotomies in two patients with lower motor neurone lesions; one had to undergo three tractotomies, the other had to have two tractotomies and one rhizotomy before the pain was relieved. Three additional patients with lower motor neurone lesions and shooting pain were treated conservatively.

There were three patients with upper motor neurone lesions who complained of burning and crushing pain in the lower extremities and abdomen; these were treated medically.

Autonomic Dysreflexia. This condition was present in three patients with complete lesions, $\mathrm{T}_{4}, \mathrm{~T} 6, \mathrm{~T}_{7}$; all of these patients, however, displayed only profuse perspiration on bladder distention without blood pressure changes but with cutis anserina. An additional two patients with incomplete cervical lesions showed the full syndrome of autonomic dysreflexia. Four of the five patients were treated conservatively; one (T6) had an alcohol block indicated by skeletal spasticity; in spite of the subarachnoid injection of $12 \mathrm{ml}$. of alcohol, a residual unilateral sweating of the body persisted.

\section{PSYCHOLOGICAL AND PSYCHIATRIC ASPECTS}

There are 12 patients who needed at one time or other psychological and psychiatric attention. Among these were two patients with chronic brain syndrome 
upon arteriosclerotic basis (aged 60 and 7I). There were two patients with suicidal attempts because of severe depressive reactions (aged 53 and 55). There were five patients with depressive reactions or anxiety states (aged 48, 55, 53, 54, 60). Three patients were classified as character disorders.

\section{INTERNAL MEDICAL ASPECTS}

Cardiovascular Problems. Coronary disease was observed in 7 patients, aged at the time of diagnosis 65,66 (2),67 (2), 68, 69 years. The manifestations were either right or left bundle branch block in seven patients and heart insufficiency in one.

Hypertensive disease was observed in five patients, aged at the time of diagnosis 53, 54, 57, 67, 68 years. In two of those patients, now aged 63 and 69, respectively, the hypertensive disease existed without demonstrable renal involvement, and could, therefore, be presumed to be of essential rather than of renal aetiology. In the remaining three patients, the hypertensive condition was classified as renal.

A recurrent unilateral phlebothrombosis of the left lower extremity was observed clinically twice in the same patient with an upper motor neurone lesion, at the respective ages of 62 and 67; he is now 72 years old and his injury dates back Io years.

The four additional cases of bilateral phlebothrombosis of the lower extremities have been diagnosed by phlebography which disclosed either partial or total venous occlusion. At the time of the diagnosis, these patients were 52, 55, 56 and 58 years of age; two had upper and two lower motor neurone lesions.

Pulmonary Problems. These were encountered in seven patients of whom three had cervical cord lesions and four had thoracic lesions. The complications consisted chiefly of atelectasis and/or pneumonia which necessitated tracheostomy in one patient with a cervical lesion and in another with a low thoracic lesion.

Gastro-intestinal Problems. Gastric ulcer had to be treated conservatively in two patients.

One patient had amoebiasis, another had homologous serum hepatitis and a third patient had pancreatitis and jaundice.

Cholelithiasis, treated with cholecystectomy, was found in one patient.

Rectal pathological findings were as follows: benign rectal polyps (histologically verified) were found in two patients, anal prolapse in two, perineal (periproctitic) abscess in one, and a fistula ani was present in one of the two patients with rectal polyps. The majority of rectal complications concerned haemorrhoids; there were Io patients ( 20 per cent.) who needed attention, but only three patients needed haemorrhoidectomy.

Metabolic Problems. Diabetes was found in three patients.

Neoplastic conditions of the skin of the face (basal cell or squamous cell) were found in six patients.

There were four patients with dermatitis (three infectious and one due to rubber allergy).

There were two benign lipomata of the subcutaneous tissue, one at the shoulder, the other at the hip in two patients, respectively. 

patients.

Degenerative, generalised arthrotic changes of the spine were observed in four

\section{PHYSICAL REHABILITATION ASPECTS}

Of the 52 patients here presented, 34 (66 per cent.) use exclusively wheelchairs for locomotion. Eighteen patients are able to ambulate as shown in Table III.

\section{TABLE III}

(a) Walking without any aid . . . . 2

(b) Walking without braces but with canes . . 2

(c) Walking without braces but with crutches . 4

(d) Walking with braces and with crutches . . 6

(e) Walking with short leg braces and with canes . 4

The level of lesions in these five categories were as follows: (a) T8, incomplete; C6, incomplete. (b) Tro, incomplete; $\mathrm{C}_{5}$, incomplete. (c) L2, incomplete; L5, incomplete; $\mathrm{C}_{4}$, incomplete; $\mathrm{C}_{5}$, incomplete. (d) Tr2, incomplete; $\mathrm{C}_{4}$, incomplete; Tro r. Li 1., complete; $\mathrm{T}_{\mathbf{1} 2}$, complete; $\mathrm{L}_{4}$, complete; $\mathrm{T}_{7}$, incomplete. (e) $\mathrm{L}_{3}$, incomplete; $\mathrm{L}_{2}$, incomplete; $\mathrm{L}_{3}$, incomplete; $\mathrm{C} 6$, incomplete.

It should be noted that all patients in categories $(c)$ and $(d)$ and two patients in category $(e)$ use the wheelchair for daily living activities and locomotion but use their ambulation ability for exercise.

Among the patients with incomplete cervical lesions, four had a BrownSéquard type of lesion.

\section{COMMENTS}

In recent years, statistical mortality reports have been published in various countries (Hastings, I959; Nyquist, I960; Burke et al., I960; Breithaupt et al., I96I; Guttmann, I962; Tribe, I963; Rossier \& Brunner, I964). The overall mortality ranged from Io to 16 per cent. At this Center the latest figure of uncorrected (including non-traumatic cases and non-injury-related mortality) was I4.6 per cent. of a total of 1948 patients.

As in a previous paper (Nyquist, I960), in this study again a discrepancy was noted regarding the mortality of patients with traumatic and non-traumatic conditions of the spinal cord. While Nyquist found the mortality of patients with non-traumatic lesions twice that of those with traumatic conditions, we found that the ratio was somewhat less, namely, 47 per cent. and 29 per cent., respectively, in the above two groups. Only Guttmann (1962) found an almost equal, if not a slightly more favourable percentage for the non-traumatic group. This is perhaps explainable on the basis of the aetiology; in our cases; poliomyelitis was absent as well as myelodysplasia.

It is interesting and not unexpected that the mortality figures according to cervical, thoracic and lumbar levels, reflected the picture of the overall mortality. Thus we find 66 per cent. versus 32 per cent., 50 per cent. versus 28 per cent., and 33 per cent. versus 20 per cent. in the non-traumatic and traumatic group, respectively.

The survival time of patients with traumatic lesions, illustrates what other 
authors (Hastings, I959; Burke et al., I960) have described, namely, that the survival time is longer when a patient is injured within the first five decades of life than when his injury occurs during or after the sixth decade. However, there was an amazing number of survivors up to Io years when the patient sustained an incomplete cervical injury in the sixth or seventh decade of life ( 17 alive, 5 deceased versus an overall picture of 17 alive and 7 deceased). On the other hand, the greatest danger to these patients is within the first five years after injury.

When the injury occurred at the thoracic levels, the survival time was yet somewhat longer (27 alive, I I deceased). As would be expected, a similar pattern obtained when the injury occurred at lumbar levels ( 8 alive, 2 deceased).

Even if one accepts a longevity of the United States population of $70 \cdot 2$ years (Fister, I963), it would appear, in accordance with Hastings (1959), that less years of life are lost to those injured in their sixth, seventh and eighth decades than before that time. Apparently, the general condition of the patient at the time of injury and the extent of the injury, not necessarily the level, play an important role for length of survival.

Although the longevity of these patients was nearing or exceeding the norm (Fister, 1963), their mortality was higher than one would expect in a general population (Breithaupt et al., I96I).

In studying the causes of death, it became apparent that these did not differ in the aged patients with non-traumatic cord lesions from all other younger patients with such conditions; the cause of death was usually related to the basic disease which led to the spinal cord dysfunction.

Per contra, the causes of death presented here among old patients with traumatic cord lesions differed conspicuously from those found in patients of a mixed age, i.e., in surveys of large patients' groups (Nyquist, I960; Breithaupt et al., I96I; Tribe, I963). It is well known that renal death is common in patients with spinal cord injuries; the present figure at this Center is 29 per cent. of all deaths. However, an incidence as high as $8 \mathrm{I}$ per cent. of all deaths in the late stage of paraplegia has been recently described (Tribe, I963). It is, therefore, of interest that the renal death toll was only 22 per cent. as compared with the death rate from cardiovascular conditions which was 39 per cent., i.e. almost twice as much.

Renal deterioration is highest between 5 and I5 years after injury (Nyquist, 1960), and one could, therefore, argue that in the group who died of cardiovascular conditions, death occurred in four instances prior to the first five-year period. On the other hand, there were three patients who died from arteriosclerotic disease 6, 45 and 48 years after injury respectively. The relatively low renal death rate is perhaps related to the relatively high incidence of incomplete lesion with their notoriously better bladder function.

The catheter-free state was reached in 52 per cent. upon discharge, which is lower than Comarr's (I96I) figure, reported for a large sample of patients from this Center. However, 52 per cent. is not too far below Comarr's (I96I) estimated number of patients (65-70 per cent.) who remain permanently catheter-free. It is of interest that among these 27 patients ( 52 per cent.) who were catheter-free only nine had a complete thoracic lesion, while all others had incomplete lesions at other levels. Among these were Io patients above the age of 60 years, in concurrence with Comarr's (1962) observation of one such case in that age. A further point of interest is the fact that I I of the 27 patients needed no urinal or appliance of any sort which only attests to the incompleteness of their lesions. 
As is well known, the return of bladder function occurred predominantly within the first year.

The incidence of renal calculosis in the patients still alive was considerably higher ( 15 per cent.) than that of 8.2 per cent. last reported from this Center (Comarr et al., 1962); the ratio of early (within 2 years) versus late calculosis (after 2 years), however, was only 25 versus 75 per cent. as compared with the previously reported ratio of 59 per cent. versus $4 \mathrm{I}$ per cent. The reason for this may again be better bladder function because of incomplete lesions.

Infectious pseudopapillomata of the lower urinary tract were observed in the patients still alive at a higher rate (Io per cent.) than in the total population of this Center during a period of more than 18 years ( 6 per cent.). These polyps are of infectious aetiology; they are not necessarily related to the presence of a catheter.

Penoscrotal pathological changes were rare among the 52 patients still alive ( 6 per cent.). In the total population of this Center the incidence is rather high (24 per cent.) as compared with the experience of the Stoke Mandeville Centre (I.5 per cent.) (Griffiths \& Walsh, I96I; Guttmann, I963). This obviously points to the advantage of intermittent catheterisation as practised in the Stoke Mandeville Centre.

Vesico-ureteral reflux of $\mathrm{I} 3$ per cent. was rather low as compared with the incidence ( 24 per cent.) of reflux encountered in the total population of 1948 patients in this Center at the time of writing.

The rate of transurethral resection was rather high (28 per cent.) among the patients still alive as compared with the total patient population (I I per cent.). The amazing part was that this procedure did not produce as good a result in patients with lower motor neurone lesions as one would expect. Only two out of six became catheter-free. It is moot to speculate whether additional operation of the external sphincter would have improved the condition. It is well known to anyone familiar with urologic problems of patients with spinal cord injury, that transurethral resections may have to be repeated and that they are occasionally necessary and effective even many years after injury.

The incidence of epididymitis was somewhat higher (3I per cent.) than that of the total population of this Center ( 23 per cent.).

Bowel function was re-educated by digital stimulation and/or suppositories in 69 per cent. of the still living patients. This number is similar to that of Maury (1963) who found it to be 7I per cent. of 227 patients.

Decubitus ulcer did not differ in regard to origin and management from that in a younger patient group.

The incidence of fractures of the lower extremities was 8 per cent., which is somewhat less than the I I per cent. reported previously from this Center (Comarr et al., I962). It was then pointed out that the incidence of fractures was lower when it concerned an age-group older than 40 years.

Laminectomy was of no avail in regard to neurological recovery. It should be stressed that this operation was done elsewhere in the majority of cases. Only about 5 per cent. of II 73 performed laminectomies were done at this Center. The indications have remained the same as originally outlined (Bors, I948) namely, open injury of the contents of the spinal canal, progressive neurologic deficit and persistent spinal fluid block.

Neither spasticity nor pain posed different problems than in a younger group of patients, and the same applied to autonomic dysreflexia. 
In this group of patients still alive about 23 per cent. were in need of psychological help. Among our presently hospitalised patient population (205 beds) from 3 I to 40 per cent. show psychologic disturbances. Only a relatively small group of them is amenable to therapy. The majority shows character disorders, resistant to treatment. It can be reiterated what was expressed by one of us (Bors, I964) that spinal cord injury does not cause either psychosis or character disorder but that the opposite is true, namely, that psychosis or character disorder may be the cause of paraplegia.

The incidence of coronary disease was high (I6 per cent.), which is not surprising in this age-group; it was more than Io times that of the total paraplegia population in which it was $\mathrm{I} \cdot 4$ per cent. among 1948 patients.

Hypertensive disease in the group presented here, was about io per cent., i.e. three times as high as that of the total paraplegia population, in which it was 3 per cent. Both coronary and hypertensive disease are undoubtedly related to general arteriosclerosis and/or progressive renal infection.

Five patients (Io per cent.) had demonstrable phlebothrombosis without pulmonary infarcts. It is known that venous occlusions of the lower extremities occur in a high percentage (58.6) (Bors et al., 1954). The incidence of pulmonary infarction has continued to be rather low at this Center, namely nine cases in a population of 1948 with five fatalities (0.3 per cent.). It should be stated, however, that these were patients transferred to our Center weeks rather than days or hours after injury. Therefore, no information is obtainable as to how many patients died during the acute phase in the United States as compared with other countries (Tribe, 1963; Rossier \& Brunner, 1964), where fatal embolism reached 8 per cent. In this connection it is of interest that pulmonary infarction was very low although anticoagulant therapy has not been used at the Long Beach Center, in spite of the high rate of phlebographically demonstrable venous occlusions.

Pulmonary complications (atelectasis) are not uncommon in patients with cervical cord involvement. In the total paraplegia population the ratio of pulmonary complication was twice as high when the lesion was cervical than when it was thoracic. This ratio did not apply to our small series.

It is interesting that duodenal ulcers have not been seen in our older patients. They occurred in about 4 per cent. of our total paraplegia population of 1948 patients. Instead we saw two patients in whom a gastric ulcer was diagnosed (4 per cent.).

Haemorrhoidectomy was necessary in about 6 per cent. of our series of aged patients; this corresponded to the 5 per cent. encountered in the total paraplegia population at this Center.

Diabetes was higher in this age-group ( 6 per cent.) as compared with the incidence of this condition in the total population at this Center ( $1 \cdot 2$ per cent.).

That neoplastic skin lesions appeared more frequently ( 12 per cent.) in this group of aged patients than in the total population seems to be self-explanatory. These skin lesions did not occur in decubitus ulcers. Only one patient, still alive but not listed in this group, underwent surgical removal of a cancer I6 years ago which had developed in a sacral ulcer. He is now 7I years old.

The astounding fact that so many of our patients ( 34 per cent.) were able to ambulate was due to the high incidence of incomplete lesions. This explained why ambulation of some type was almost three times as frequent than that reported in a previous study from this Center, when it was observed in only I 2 per cent. of 858 
patients (Comarr \& Kaufman, 1956). Although it was not necessarily the age but rather the extent of the lesion which determined the possibility of ambulation, the wheelchair remained the main means of locomotion of the majority of patients who were able to ambulate. This confirms previous reports by Maury (I963) and Rossier (1964).

\section{SUMMARY}

I. A survey of patients is reported who were alive in their seventh decade and later or who have died in their seventh decade or later.

2. The two groups contained 32 patients with non-traumatic and 73 patients with traumatic lesions of the spinal cord and/or cauda equina, respectively.

3. The mortality rate in the non-traumatic group was higher than in the traumatic group (47 per cent. and 29 per cent., respectively); the causes of mortality have been enumerated and discussed.

4. The 52 living patients with traumatic lesions were studied in detail in regard to $(a)$ urological aspects, $(b)$ bowel function, $(c)$ decubitus ulcer, $(d)$ orthopaedic aspects, $(e)$ neurological and neurosurgical aspects, $(f)$ psychological and psychiatric aspects, $(g)$ internal medical aspects, and $(h)$ physical rehabilitation aspects.

5. The observations are discussed in the light of the literature.

6. The study indicated that the general condition of the patient and the extent but not the level of injury were the determining factors for the length of survival.

\section{RÉSUMÉ} plus.

I. L'enquête porte sur deux groupes de malades vivants ou morts l'age de 70 ans ou

2. Les deux groupes comportent 32 patients non traumatiques et 73 avec lésions traumatiques de la moëlle ou de la queue de cheval, respectivement.

3. Le pourcentage de la mortalité est plus important dans le groupe des non-traumatiques ( $47 \%$ et $29 \%$ respectivement); les causes de la mortalité ont été énummérées et discutées.

4. Les 52 malades vivants avec une lésion traumatique ont été étudiés dans le detail en raison des aspects urologiques, fonction intestinale, escharres, sequelles orthopediques, des manifestions neurologiques et neuro-chirurgicales, des reactions psychologiques et psychiatriques, des complications médicales, et, enfin, des aspects de la réadaptation.

5. Les observations sont discutées à la lumière de la littérature courante.

6. Cette étude indique que la condition générale du malade et son atteinte, mais non pas la hauteur de la lésion, sont les facteurs déterminants de la survie.

\section{ZUSAMMENFASSUNG}

I. Es wird über eine Gruppe von Patienten berichtet, die zwischen 60 und 70 Jahre alt waren, oder die im Alter von 60 oder später sterben.

2. Die zwei Gruppen umfassten 32 Patienten mit non-traumatischen Läsionen und 73 Patienten mit traumatischen Läsionen des Rückenmarks oder der Cauda equina.

3. Die Mortalität war höher in der non-traumatischen Gruppe als bei traumatischen Fällen ( $47 \%$ verglichen mit $29 \%$ ).

Die Todesursachen werden aufgezählt und erörtert.

4. 52 Patienten, die überlebten nach traumatischen Läsionen, wurden genau nachuntersucht nach urologischen, darmfunktionellen, dekubitus, orthopädischen, neurologischen und neuroschirurgischen, internistischen, psychologischen und psychiatrischen und Rehabilitations-Gesichtspunkten.

5. Die Untersuchungen werden zusammen mit den Resultaten aus der Literatur erörtert. 
6. Diese Arbeit zeigt, dass Allgemeinzustand und das Ausmass der Veletzungsfolgen, aber nicht das Niveau der Lähmung, grundlegend für die Lebensdauer des Patienten waren.

\section{REFERENCES}

Bors, E. (1948). Spinal Cord Injuries, Veterans Adm. tech. Bull., TB 10-503, I 5 December 1948.

Bors, E. (I964). Briefing of the Veterans Administrator, 26 May 1964.

Bors, E., Conrad, C. A. \& Massell, T. B. (I954). Surg. Gynec. Obstet. 99, 45 I.

Breithaupt, D. J., Jousse, A. T. \& Wynn-Jones, M. (I96I). Canad. Med. Assoc. F. 85, 73.

Burke, M. H., Hicks, A. F., Robins, M. \& Kessler, H. (I960). F. Amer. med. Ass. I72, I2 I.

COMARR, A. ESTIN (I96I). F. Urol. 86, 403.

Comarr, A. Estin (I962). F. Indian Med. Prof. 9, 4297.

Comarr, A. E., Hutchinson, R. H. \& Bors, E. (1962). Amer. F. Surg. 103, 732.

ComarR, A. E. \& KaUfman, A. A. (1956). F. Neurosurg. 13, 95.

Comarr, A. E., Kawaichi, G. K. \& Bors, E. (I962). F. Urol. 87, 647.

Fister, G. M. (1963). Today's Health 41, 6.

Griffiths, I. H. \& WaLSh, J. J. (I96I). Brit. F. Urol. 33, 374.

Guttmann, L. (1962). Mon. Bull. Minist. Hith. Serv. 21, 60.

Guttmann, L. (1963). Personal Communications to E. B., 3I May 1963.

Hastings, J. E. F. (1959). A Study of the Paraplegic Patient. Ontario: Workmen's Compensation Board.

Maury, M. (1963). Ann. Méd. Phys. 3, 203.

Nypuist, R. H. (I960). Proceedings of the gth Annual Clinical Spinal Cord Injury Conference, Long Beach, California, p. I09.

Rossier, A. (I964). De la rééducation des traumatisés médullaires. Monography, Acta Clinica Geigy, No. 3, in print.

Rossier, A. \& BRUNner, A. (I964). Schweiz. med. Wschr. 94, 362.

Tribe, C. R. (1963). Int. F. Paraplegia, I, I9. 